\title{
MEMBANGUN SERVER BERBASIS LINUX PADA JARINGAN LAN DI LABOR SISTEM INFORMASI JURUSAN TEKNOLOGI INFORMASI POLITEKNIK NEGERI PADANG
}

\author{
Rasyidah \\ Jurusan Teknologi Informasi, Politeknik Negeri Padang \\ fifi_sayid_f@yahoo.com
}

\begin{abstract}
The System Information Laboratory of Information Technology Department Polytechnic State of Padang has 30 units computer as education facilities to support learning process. All of computers used at same time in a learning section. This case causing trouble to monitoring each students activities.

In order to get the solution for the lecturer, the writer then construct a server by using Linux operation system and client by using windows system operation in which Samba File Server is needed. By using this samba, the lecturer will be able to share the data and will be able to use the server as data storage media. Besides that, the writer will also use VNC (Virtual network connection) to simplify the process of monitoring and supervising client working system. Based on the result gotten after the writer done some experiment, it can be concluded that Samba File Server can also be used after some configuration is applied on certain files. Moreover, the writer also conclude that VNC can control the entire of the client. The writer suggests that Samba File server which will be used is the latest version one which has more feature than the previous one, it is suggested that the configuration of VNC is applied on Ubuntu Linux since the service is available.
\end{abstract}

Kata Kunci : Samba File Server, VNC, Ubuntu installation

\section{PENDAHULUAN}

Dalam dunia pendidikan, komputer sudah berkembang dengan sangat pesat, kecepatan, kenyamanan dan kemudahan dalam proses pembelajaran sangat berpengaruh untuk meningkatkan kualitas dari mahasiswanya. Disamping itu seorang pengajar harus mempunyai kehandalan dan kecakapan dalam mengantisipasi hal-hal yang terjadi pada jaringan komputer. Pengajar harus mampu mengontrol kegiatankegiatan mahasiswanya.

Proses belajar mengajar yang berlangsung di Politeknik Negeri Padang khususnya jurusan Teknologi Informasi, pada umumnya sudah banyak menggunakan fasilitas komputer. Salah satu labor yang digunakan sebagai tempat pembelajaran ini adalah labor sistem informasi. Labor ini memiliki 30 unit komputer yang dapat digunakan mahasiswa dan satu unit komputer yang digunakan pengajar. Pada saat labor ini digunakan, semua komputer yang ada di labor tersebut digunakan oleh mahasiswa sebagai alat bantu pembelajaran. Hal ini tidak menuntut kemungkinan mahasiswa yang pengecualian melakukan kegiatan atau membuka aplikasi diluar mata kuliah yang sedang diajarkan. Untuk itu dibutuhkan pengontrolan prima dari pengajar. Masalah yang timbul adalah ketidak sanggupan pengajar melakukan pengontrolan tersebut karena akan mengganggu materi yang akan diberikan.
Dalam hal ini dibutuhkan sebuah server yang dapat mengontrol kegiatan-kegiatan yang dilakukan mahasiswa tersebut. Sehingga kenyamanan dan kemudahan dalam belajar sangat dirasakan. Pengajar tidak perlu repot mendatangi setiap mahasiswa yang sedang menghadapi komputernya masing-masing untuk memantau aplikasi apa yang sedang digunakannya. Sebelum itu, dengan adanya server ini mahasiswa yang akan menggunakan komputer harus terlebih dahulu mendapat izin akses dari server.

Sesuai dengan latar belakang yang telah dijelaskan diatas, maka dirumuskan pokok-pokok permasalahan :

1. Bagaimana membangun dan mengimplementasikan sebuah server berbasis linux pada jaringan LAN.

2. Bagaimana menghubungkan klien yang menggunakan sistem operasi Windows dengan server linux.

3. Bagaimana agar server linux dapat melakukan sharing data ke klien.

4. Bagaimana agar server linux mampu melihat aktivitas yang dilakukan oleh PC klien (remote desktop) 


\section{DASAR TEORI}

\subsection{Jaringan Komputer}

Jaringan komputer adalah sekelompok komputer otonom yang saling berhubungan satu dengan yang lainnya menggunakan protocol komunikasi melalui media komunikasi sehinga dapat saling berbagi informasi, aplikasi dan perangkat keras secara bersama-sama.(Anjik dan Rianto, $2008: 1$ )

\subsection{Linux}

Linux adalah sebuah program open source yang gratis di bawah lisensi GNU, sistem operasi 32-64 bit, yang merupakan turunan dari Unix dan dapat dijalankan pada berbagai macam platform perangkat keras mulai dari Intel (x86), hingga prosesor RISC.

\subsection{Samba File Server}

Samba merupakan implementasi dari protokol SMB (Server Message Block) pada sistem UNIX. Protokol ini digunakan oleh MSWindows NT untuk File dan Printing Sharing Service. Dengan mengaktifkan samba pada mesin Linux kita maka kita dapat berbagi file dan printer dengan Windows. Dengan kata lain, dengan menjalankan Samba, maka suatu server Linux dapat tampak seperti suatu Windows Server bagi mesin Windows lainnya.

\subsection{VNC (Virtual Network Computing)}

VNC merupakan grafik desktop untuk sistem sharing dengan menggunakan protocol RFB(Remote Frame Buffer) yang digunakan untuk mengatur komputer lain secara jarak jauh. VNC mengirimkan informasi penekanan tombol keyboard dan klik pada mouse sehingga dapat mengontrol komputer lain pada jaringan yang menampilkan layar pada komputer pengontrol.

VNC bersifat platform-independent, artinya server dapat terhubung dengan klien walau berbeda sistem, operasi VNC banyak digunakan dalam hal remote technical support, akses file dari komputer di rumah ke komputer tempat kerja. VNC tersedia secara grafis dan digunakan oleh jutaan manusia.

Protokol Remote Frame Buffer (RFB) bekerja pada jaringan TCP/IP. Setiap informasi yang dikirim dari server dapat menyebabkan klien menggambarkan sesuatu di lapisan atasnya. Ada beberapa metode yang membuat pengiriman informasi menjadi optimal sehingga tidak memberatkan bandwidth. Walau terkadang informasi yang dikirimkan hanyalah perubahan saja, dan bukannya informasi untuk suatu desktop. Hal tersebut sangatlah jelas bahwa menghemat bandwidth.

VNC berbeda dengan remote display system lain seperti X server pada PC. Faktor penting yang membedakan $\mathrm{VNC}$ dengan remote display system semacam X server adalah: a. Sepenuhnya cross-platform/ platform independent. Desktop Linux bisa ditampilkan di Windows PC ataupun Linux PC

b. Berukuran kecil dan sederhana

c. Sharable. Satu desktop bisa ditampilkan dan dipergunakan oleh banyak viewer pada satu saat.

d. Gratis, kita bisa mengunduhnya dan menggunakannya sesuai GNU General Public License.

\section{METODOLOGI}

Penelitian yang akan dilakukan jika dilihat dari tujuannya adalah penelitian terapan, karena penelitian dilakukan untuk memecahkan sebuah masalah. Sedangkan pada prosesnya akan melibatkan metode penelitian survey, penelitian action research dan penelitian evaluasi.

\subsection{Tahapan Penelitian}

a. Studi Pustaka

Studi Pustaka dilakukan untuk mengumpulkan dan mempelajari referensi dan teori-teori pendukung yang berkaitan dengan objek penelitian.

b. Analisis Kebutuhan

Analisis kebutuhan untuk mengetahui kebutuhan fungsional dan non fungsional yang diinginkan.

c. Perancangan

Merancang jaringan untuk koneksi. Kemudian melakukan konfigurasi terhadapnya agar dapat berkomunikasi antara Windows dan Linux.

d. Implementasi

Mengimplementasikan Samba pada server untuk koneksi jaringan. Kemudian melakukan konfigurasi terhadapnya agar dapat berkomunikasi antara Windows dan Linux.

e. Pengujian

Setelah jaringan selesai dibuat, selanjutnya dilakukan pengujian yaitu uji coba koneksi jaringan dan berbagi data.

f. Perbaikan Aplikasi

Berdasarkan hasil pengujian, dilakukan perbaikan jika ditemukan kelemahankelemahan pada jaringan.

g. Publikasi

Jika proses perbaikan telah selesai selanjutnya dilakukan publikasi terhadap jaringan . 


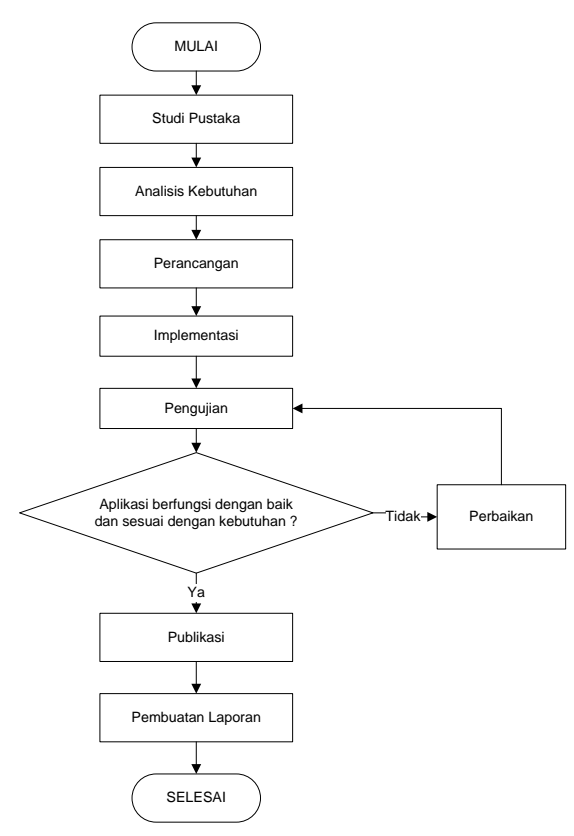

Gambar 3.1 Tahapan Pembanguna Aplikasi

\subsection{Lokasi Penelitian}

Penelitian secara umum dilakukan di Labor Sistem Informasi Jurusan Teknologi Informasi Kampus Politeknik Negeri Padang, Sumatera Barat.

\section{PEMBAHASAN}

\subsection{Rancangan Jaringan}

Rancangan jaringan di labor perkuliahan Sistem Informasi jurusan Teknologi Informasi Politeknik Negeri Padang seperti topologi star. Tiap-tiap workstation akan terhubung ke server melalui perangkat switch. Gambar topologi jaringan yang ada di labor perkuliahan Sistem Informasi jurusan Teknologi Informasi Politeknik Negeri Padang adalah seperti gambar 4.1.

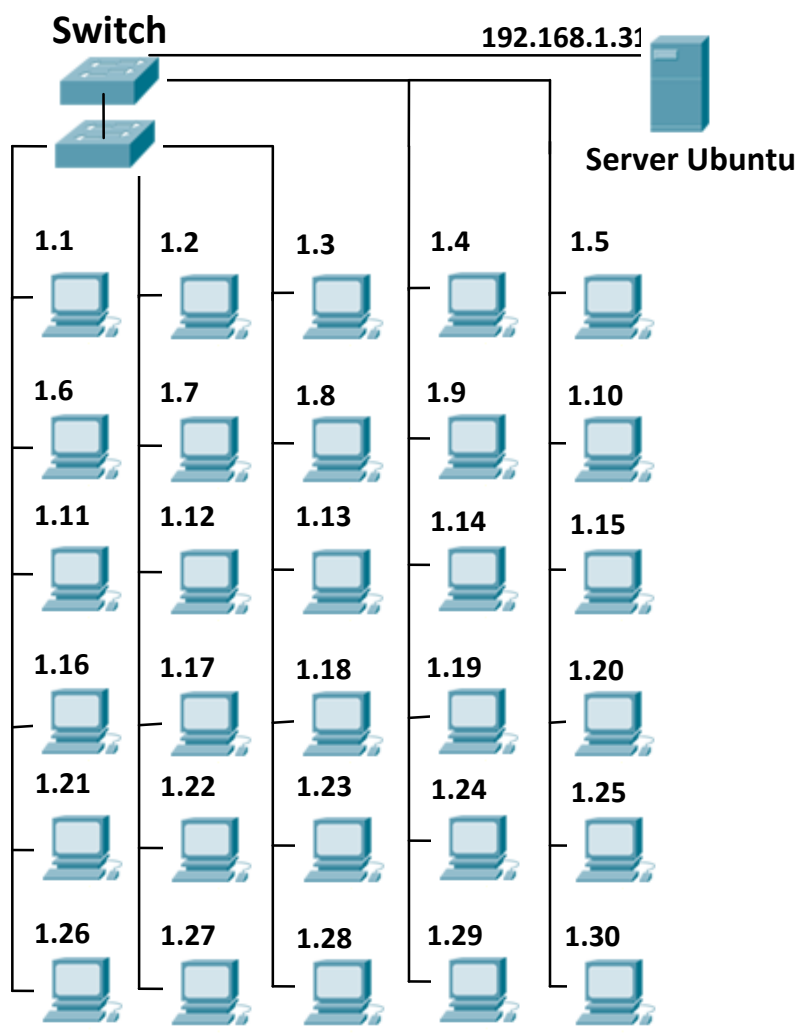

Gambar 4.1 Jaringan Labor Sistem Informasi

IP address yang digunakan adalah kelas C:

- $\quad$ IP server 192.168.1.31

- $\quad$ IP klien 192.168.1.1 - 192.168.1.30

Subnet mask yang digunakan adalah 255.255.255.192

Labor Sistem Informasi jurusan Teknologi Informasi Politeknik Negeri Padang ini memiliki 30 unit komputer yang digunakan sebagai klien dan 1 unit komputer yang dijadikan server. Server ini menggunakan sistem operasi Linux Ubuntu versi 9.10. Selain 31 unit komputer terdapat juga 2 buah switch yang digunakan utnuk menghubungkan komputer-komputer yang ada. Topologi jaringan yang digunakan untuk menghubungkan komputer tersebut berbentuk start, karena melihat dari keuntungan yang diberikan oleh topologi ini.

\subsection{Topologi Jaringan yang Digunakan}

Topologi jaringan yang digunakan pada jaringan LAN labor perkuliahan Sistem Informasi jurusan Teknologi Informasi Politeknik Negeri Padang adalah topologi start. Topologi ini paling banyak digunakan pada jaringan kantor atau jaringan yang sifatnya lebih besar dengan banyak komputer. Klien dihubungkan ke switch dan switch dihubungkan ke sever. Topologi ini memiliki keunggulan diantaranya jika ada salah satu klien yang terputus maka klien yang lain tidak akan terganggu. Penambahan klien juga cukup mudah dilakukan dan tidak akan mengganggu klien yang lain. Namun topologi pada jaringan labor 
perkuliahan Sistem Informasi jurusan Teknologi Informasi juga memiliki kekurangan yaitu boros dalam penggunaan kabel.

\subsection{Konfigurasi Server yang Dibangun}

Server yang akan dibangun di labor perkuliahan Sistem Informasi jurusan Teknologi Informasi ini berguna sebagai administrator. Server menggunakan sistem operasi Linux, untuk tugas akhir kali ini akan mengguunakan Linux Ubuntu Desktop 9.10. Ubuntu versi ini merupakan versi terbaru dari keluaran Linux Ubuntu. Keunggulan dari linux Ubuntu ini dibanding dengan yang lainnya adalah kestabilannya.

Untuk jenis paket linux Ubuntu yang digunakan dalam membangun server ini adalah Ubuntu GUI mode. Tampilan dari desktop mirip tampilan dari windows. Sehingga lebih memudahkan seorang administrator dalam hal memonitoring aktifitas klien ataupun melakukan aktifitas-aktifitas server lainnya. Fitur-fitur yang disediakan Ubuntu juga tidak kalah dengan Windows, diantaranya:

a. Ubuntu telah menyediakan fasilitas remote desktop tanpa harus melakukan instalasi software.

b. Ubuntu dapat dijadikan router, server maupun sekedar digunakan sebagai komputer desktop biasa

c. Dan fitur-fitur yang lainnya juga telah disediakan oleh Ubuntu 9.10.

Ada 3 fungsi utama dari server yang akan dibangun ini yaitu remote desktop, sharing file dan media penyimpanan bersama :

\section{a. Remote Desktop}

Remote desktop merupakan suatu fasilitas dalam jaringan komputer dimana memiliki suatu kemampuan untuk melihat aktifitas yang sedang dilakukan oleh klien. Kegiatan ini dilakukan oleh server. Server akan mampu melakukan monitoring klien dengan remote desktop ini. Dalam hal ini remote desktop yang dilakukan adalah remote desktop dari server linux ke klien windows. Untuk itu dibutuhkan suatu aplikasi yang mampu menangani masalah tersebut, yaitu VNC(Virtual network Computing). Ubuntu 9.10 yang dijadikan server kali ini telah menyediakan fasilitas VNC sebagai fasilitas remote desktop-nya. VNC hanya akan diinstalkan terlebih dahulu pada klien yang menggunakan sistem operasi Windows. Untuk sistem operasi Windows gunakan RealVnc yang bisa didapatkan dari internet secara opensource dengan alamat URL http://www.realvnc.com.

\section{b. Sharing File}

Kegunaan lain dari server yang akan dibangun ini adalah kemudahan dalam berbagi data. Klien tidak perlu lagi mengkopi data menggunakan media pengkopian seperti flash disk dan sebagainya, namun cukup melakukan sharing dari data yang asli tersebut. Seorang administrator juga bisa melakukan sharing data ini dari server linux ke klien windows. Dalam hal sharing file dari linux ke windows ini, juga dibutuhkan suatu aplikasi agar mampu melakukan sharing antara dua sistem operasi yang berbeda ini. Untuk itu aplikasi yang akan digunakan adalah Samba File Sharing. Samba merupakan implementasi dari protokol SMB (Server Message Block) pada sistem UNIX. Protokol ini digunakan oleh MS Windows NT untuk File dan Printing Sharing Service. Dengan mengaktifkan samba pada mesin Linux kita maka kita dapat berbagi file dan printer dengan Windows 95/98 atau Windows NT/Xp.

\section{c. Media Penyimpanan Bersama}

Seorang administrator tentu ingin data dari masing-masing klien bisa dilihat langsung dari komputer server, tanpa harus melihat langsung ke komputer klien. Dalam hal ini, tempat penyimpanan berada pada sisi server. Klien yang akan melakukan penyimpanan data dapat menyimpan datanya pada harddisk dari server ini melalui Samba File Sharing. Karena samba menyediakan file-file untuk menjalankan tugas yang diinginkan maka dalam membangun server ini digunakan Samba-3.5.0.

\subsection{Perangkat-Perangkat yang Digunakan}

Perangkat-perangkat yang digunakan untuk tugas akhir ini adalah komputer server, klien, kartu jaringan, kabel jaringan dan switch.

a. Komputer Server

Komputer yang akan digunakan untuk sebagai server ini merupakan komputer buil- up dengan spesifikasinya sebagai berikut:

- Processor Pentium Core 2 Duo.

- Harddisk berkapasitas $80 \mathrm{~GB}$.

- Kartu memori berkapasitas 1 GB.

- Memiliki 1 buah NIC (Network Interface Card) atau kartu jaringan.

- Sistim operasi Ubuntu 9.10.

b. Komputer Klien

Untuk komputer yang digunakan sebagai klien juga komputer built-up seperti halnya komputer server dengan spesifikasi sebagai berikut:

- Processor Pentium 4.

- Harddisk berkapasitas 80 GB.

- Kartu memori berkapasitas 512 MB.

- Memiliki 1 buah NIC pada tiap-tiap klien.

- Sistem operasi Windows XP SP 2.

c. Kartu Jaringan

Kartu jaringan yang akan digunakan untuk menghubungkan masing-masing klien pada jaringan labor perkuliahan Sistem Informasi jurusan Teknologi Informasi adalah kartu jaringan yang menggunakan kabel UTP (Unshielded Twisted Pair) dan konektor RJ-45. Karena komputer yang digunakan adalah 
komputer built up maka motherboadnya sudah memiliki kartu jaringannya sendiri.

d. Kabel Jaringan

Kabel jaringan yang akan digunakan pada jaringan ini adalah UTP CAT5 dan konektor RJ-45. Kabel UTP CAT5 ini memiliki kecepatan 100 MBits transfer/22 db.

e. Switch

Switch yang digunakan pada labor Sistem Informasi ini adalah switch yang memiliki port yang berjumlah banyak. Perhatikan gambar 4.2 berikut.

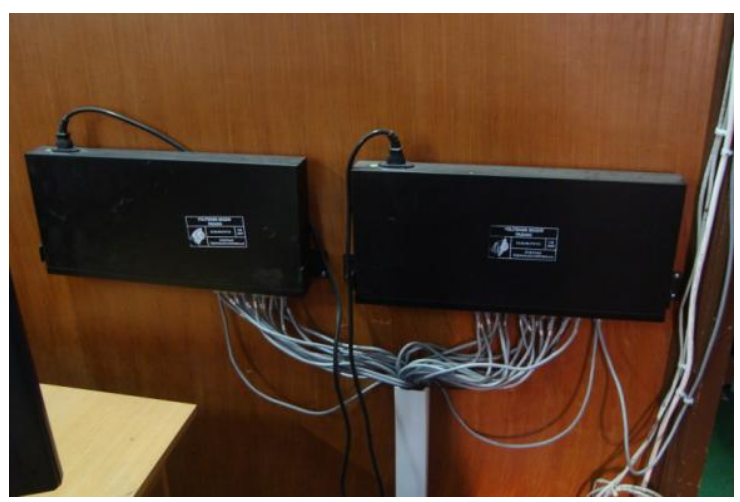

Gambar 4.2 Switch yang ada pada Labor Sistem Informasi

\subsection{Implementasi}

Server yang akan dibangun ini merupakan server pusat pada jaringan LAN (Local Area Network). Server ini berfungsi sebagai pengendali jaringan LAN tersebut. Dari server ini, yang bisa dilakukan diantaranya melihat desktop dari klien yang terhubung padanya, melakukan sharing data pada klien yang menggunakan sistem operasi Windows dan membuat tempat penyimpanan bersama dari klien di server.

Implementasi dari server ini adalah di labor perkuliahan Sistem Informasi jurusan Teknologi Informasi Politeknik Negeri Padang. Labor ini memiliki jaringan komputer yang belum menggunakan server. Jumlah klien yang terhubung ke jaringan ini adalah 30 klien. Banyaknya klien membutuhkan suatu administrasi yang bisa dilakukan oleh seorang administrator. Karena itulah dibangun sebuah server untuk mengatasi masalah tersebut. Langkah-langkah yang dilakukan dalam membangun server ini adalah:

1. Menginstalasi Ubuntu 9.10.

2. Menginstalasi Samba File Sharing dan Konfigurasi Samba.

a. Konfigurasi Samba sebagai PDC

b. Mengakses PDC dari Windows

3. Menginstalasi dan konfigurasi VNC di Windows.

4. Mengkonfigurasi IP address pada server dan klien.

\subsection{Pengujian}

Setelah melakukan instalasi dan konfigurasi software sebagai persiapan pengujian pada masingmasing server dan klien selanjutnya akan dilakukan pengujian sesuai dengan rumusan masalah

\subsubsection{Pengujian LAN}

Untuk memastikan jaringan LAN berhasil dihubungkan atau tidaknya, lakukan tes koneksi dengan utility ping.

\section{Tes koneksi antar klien}

Untuk mengetes koneksi jaringan ini gunakan utility ping pada terminal console. Tes koneksi pada gambar 4.3 berikut adalah dari komputer yang memiliki IP address 192.168.1.4 ke komputer yang memiliki IP address 192.168.1.5 $\sim$ ping 192.168.1.5 $\rightarrow$ tes koneksi ke komputer klien2

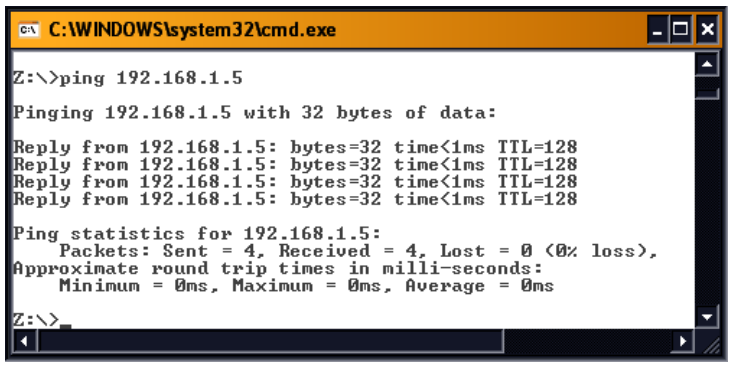

Gambar 4.3 Ping antar klien

\section{Tes Koneksi Server ke Klien}

gambar 4.4 merupakan tes koneksi dari komputer server ke salah satu komputer klien yang memiliki IP address 192.168.1.4

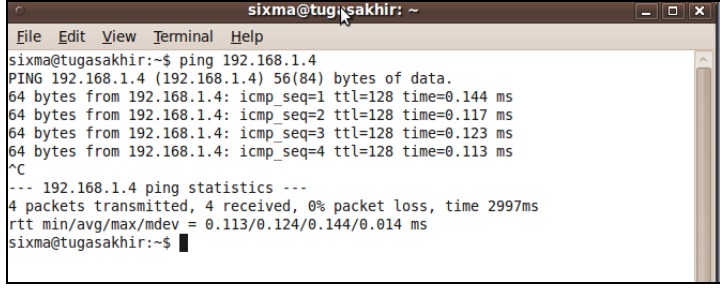

Gambar 4.4 Ping dari server ke klien

\subsubsection{Pengujian Samba File server}

Pada pengujian kali ini adalah bagaimana klien dapat langsung menyimpan file dalam driver yang telah di-share. Berikut langkah kerjanya:

1. Setelah berhasil join dalam domain "lab2" lakukan restart pada komputer klien maka akan muncul tampilan yang menghendaki menekan tombol Ctrl+Alt+Del, secara bersamaan, perhatikan gambar 4.5 


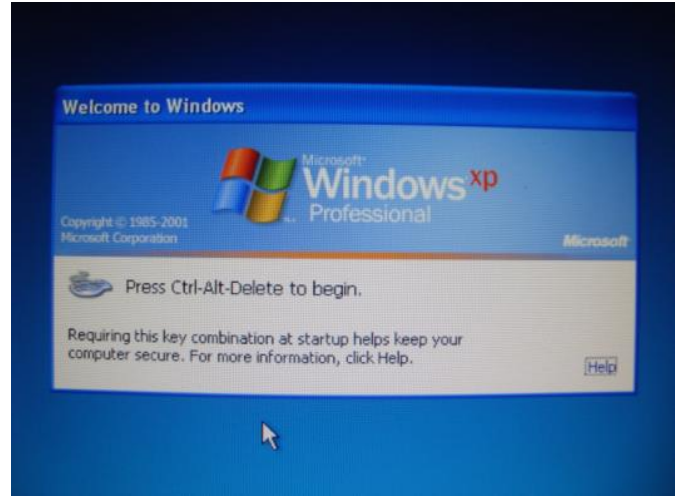

Gambar 4.5 Tampilan Awal PDC

2. Setelah itu akan muncul tampilan yang meminta untuk meng-inputkan username, password dan $\log$ on to. Perhatikan gambar 4.6
username
: mahasiswa
password
: [mahasiswa]
$\log$ on
: LAB2

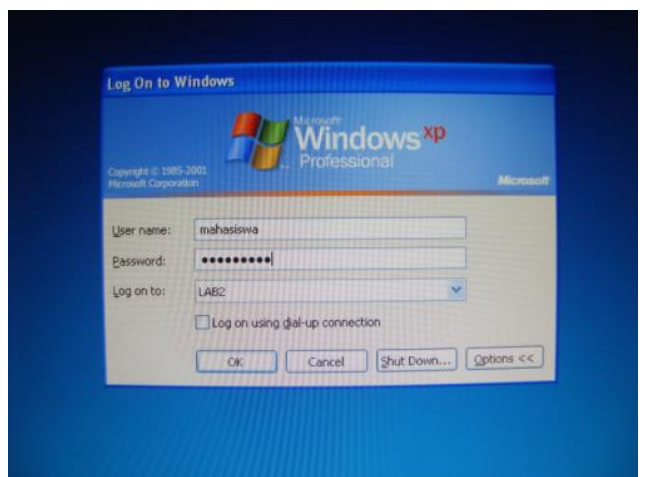

Gambar 4.6 Tampilan login PDC oleh user Mahasiswa

3. Tekan OK pada gambar di atas maka akan masuk ke Windows. Untuk mencobakan penyimpanan file seperti yang djabarkan di atas, buka MS.Word dan coba ketikkan sesuatu seperti yang terlihat pada gambar 4.7 berikut:

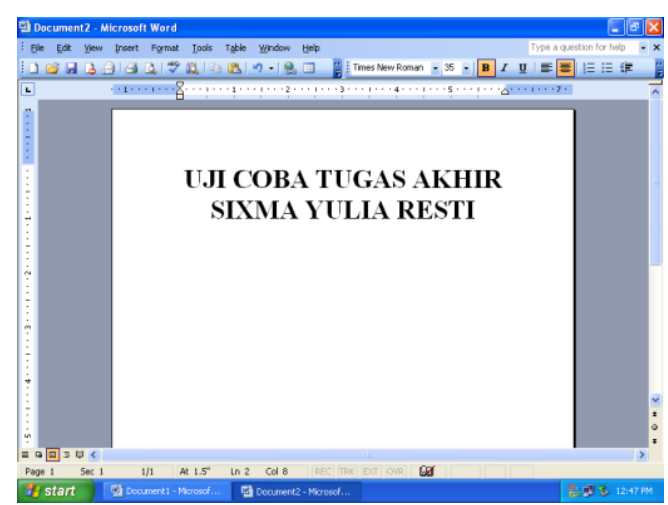

Gambar 4.7 Tampilan File yang akan di-share

4. Kemudian simpan file pada directory yang telah di-share, simpan dengan nama file "uji coba", perhatikan gambar 4.8 dan gambar 4.9 berikut.

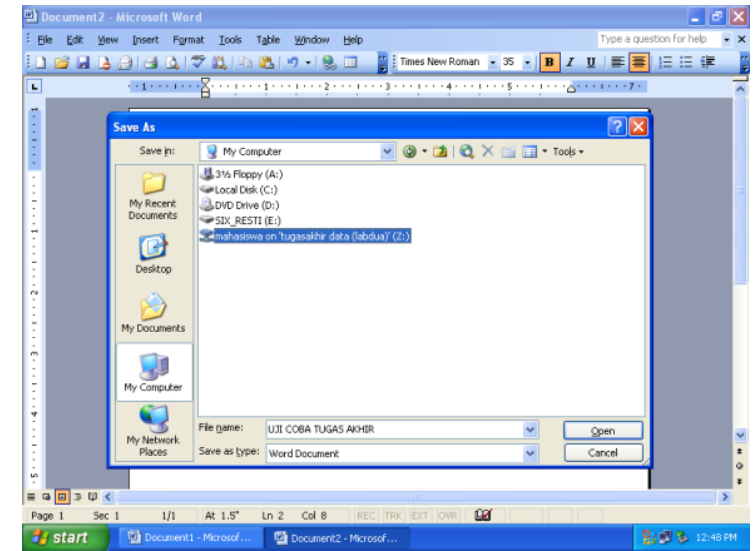

Gambar 4.8 Meyimpan file yang di-share

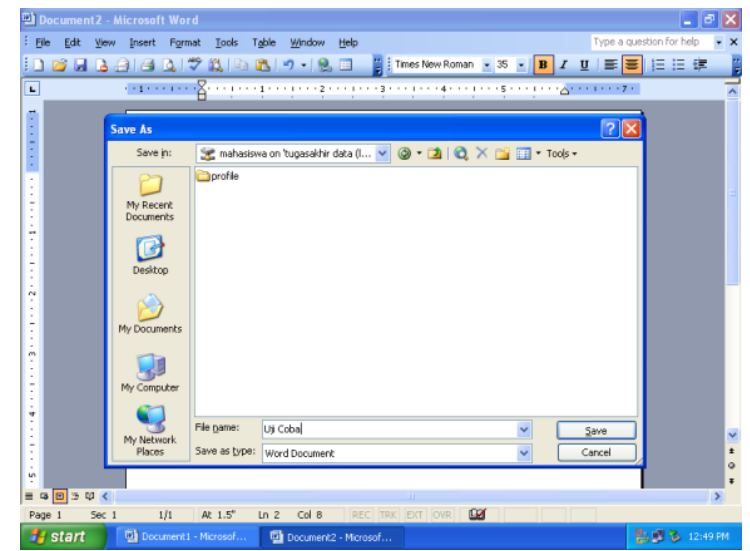

Gambar 4.9 Meyimpan file yang di-share

5. File dari klien telah disimpan. Selanjutnya adalah melihat file tersebut di server. Buka File System - Home - Mahasiswa, maka terlihat file yang telah berhasil di-share, perhatikan gambar 4.10.

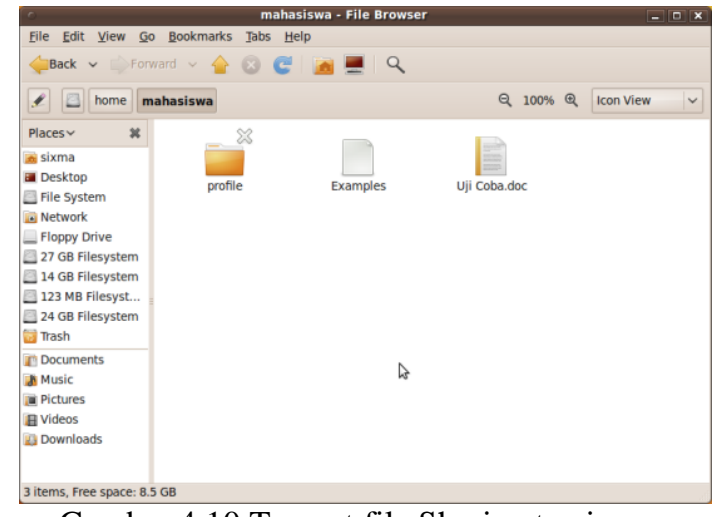

Gambar 4.10 Tempat file Sharing tersimpan

6. Buka file "uji coba" tersebut maka terlihat isinya sama dengan file yang disimpan dari komputer klien, lihat gambar 4.11 


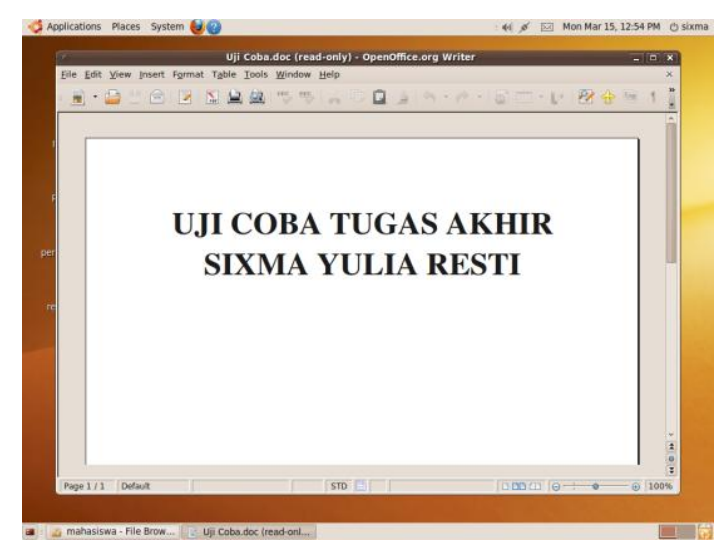

Gambar 4.11 Melihat hasil share file di server

File yang di-sharing dapat diubah izin aksesnya dari terminal yang ada di server.

1. Buka terminal console, kemudian masuk ke dalam directory yang telah di share, perhatikan gambar 4.12:

$\sim \$$ sudo su

\# cd /home/mahasiswa

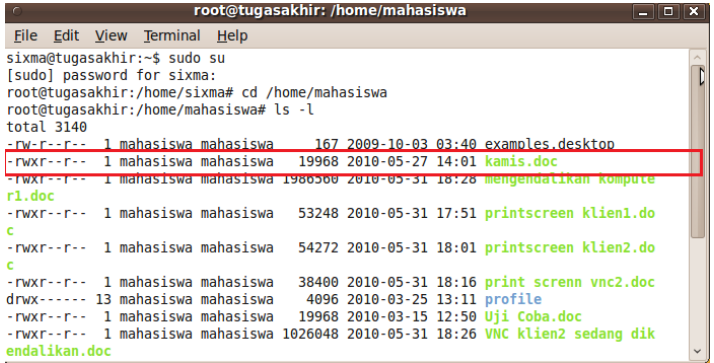

Gambar 4.12 Directory Samba

2. Pada gambar 4.12 terlihat hak akses yang diberikan pada file sharing adalah 744 maksudnya file dapat diakses penuh oleh user, hanya dapat dibaca oleh group yang lainnya. Untuk mengubah izin akses file sharing gunakan sintak chmod

\# chmod 666 kamis.doc

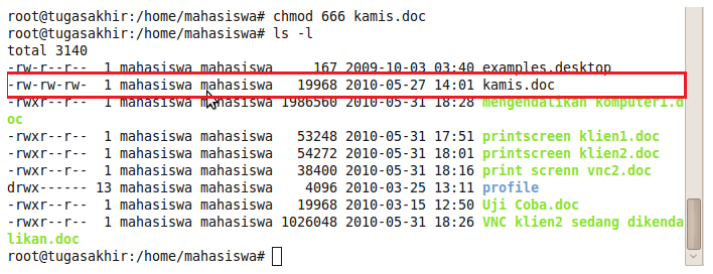

Gambar 4.13 Hak Akses yang Telah Diubah

\subsubsection{Pengujian VNC}

\section{Remote Desktop Server Klien}

Mengendalikan komputer klien Windows dari server dengan sistem operasi linux Ubuntu. Langkah kerja yang dilakukan adalah:

a. Klik application - internet - remote desktop, perhatikan gambar 4.14

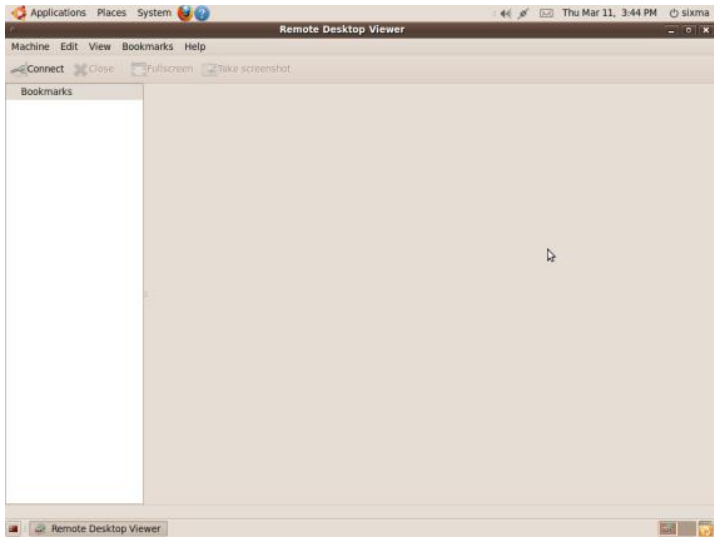

Gambar 4.14 Tampilan remote desktop

b. Klik connect - kemudian masukkan alamat IP klien yang akan di remote, IP yang digunakan sekarang adalah 192.168.1.4 - Connect. Lihat gambar 4.15.

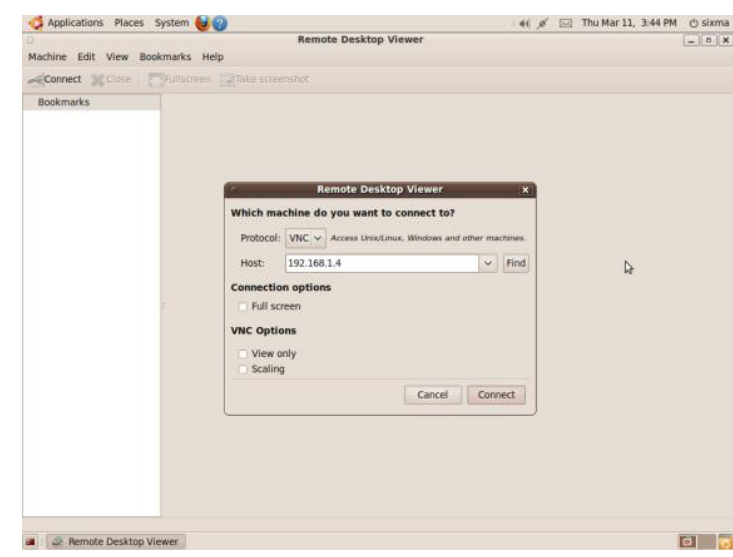

Gambar 4.15 Tampilan remote desktop

c. Selanjutnya tampil halaman Windows dari klien. Saat ini klien sedang membuka command prompt untuk melakukan ping. Perhatikan gambar 4.16.

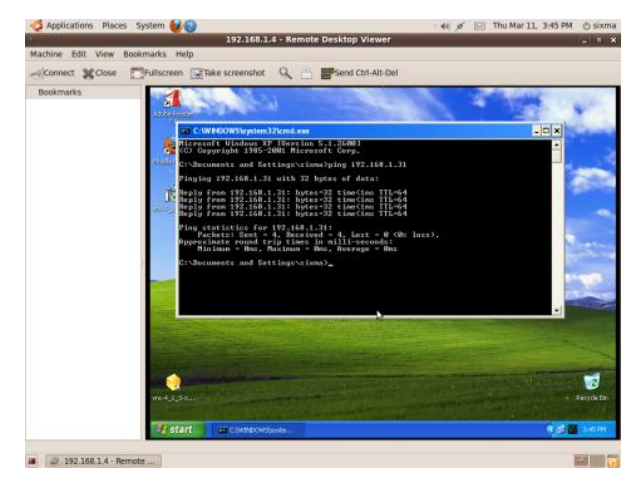

Gambar 4.16 Tampilan remote desktop untuk Windows 

selesai.

Proses pengujian VNC dari linux ke Windows

\section{a. Remote Desktop Server Klien}

Klien yang digunakan masing-masing menggunakan sistem operasi Windows Xp SP2. klien juga telah dilengkapi dengan aplikasi VNC yang diset sebagai VNC Server dan VNC Viewer. Untuk mengendalikan klien lain dari satu klien juga bisa dilakukan dengan menggunakan VNC ini. Caranya:

a. Aktifkan VNC Viewer di komputer yang digunakan untuk meremote

Start - all program - RealVNC - Run VNC Viewer

b. Isikan IP address komputer tujuan, perhatikan gambar 4.17 berikut:

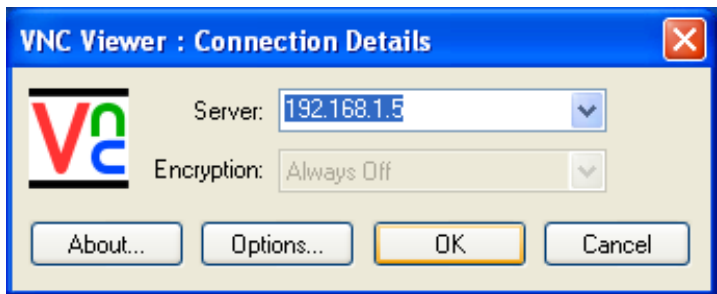

Gambar 4.17 Input IP address komputer tujuan

1. Isikan password yang digunakan untuk VNC ini, perhatikan gambar 4.18.

\section{VNC Viewer : Authentication [No Encryption]}

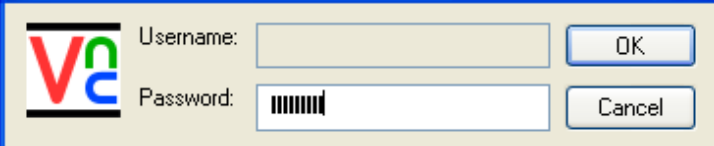

Gambar 4.19 Input password Komputer Tujuan

2. Pada komputer tujuan akan tampil jendela verifikasi dari komputer yang meremote. Perhatikan gambar 4.20 berikut :

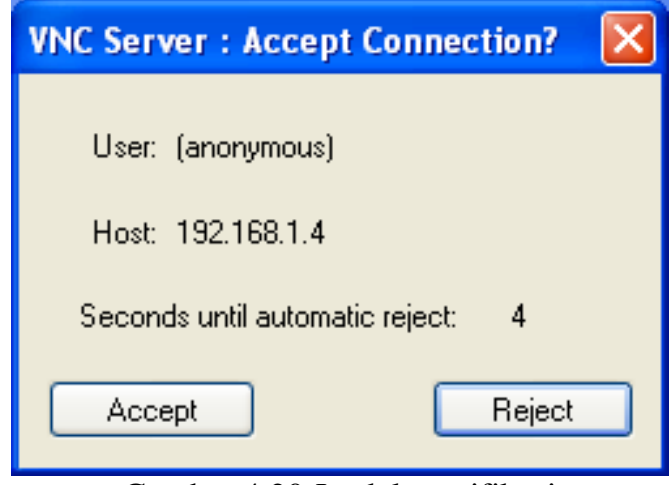

Gambar 4.20 Jendela verifikasi

3. Pilih accept untuk mengizinkan koneksi. Maka akan tampil jendela komputer tujuan di komputer yang meremote. Pada komputer tujuan akan terlihat icon VNC yang sedang aktif. Perhatikan gambar 4.21 berikut:

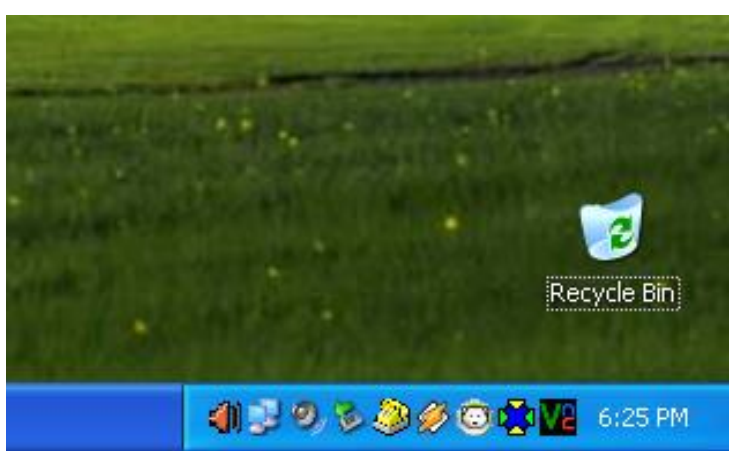

Gambar 4.21 Icon VNC yang sedang dikendalikan

\subsection{Analisa}

Pengujian ini telah berhasil dijalankan, halhal yang dilakukan adalah melakukan remote desktop, sharing data dan menjadikan server sebagai media penyimpanan data bersama.

1. Sharing File dan penyimpanan data bersama dengan Samba File Sharing

Pada Ubuntu 9.10 telah memiliki paket Samba, sehingga mudah melakukan instalasi dan konfigurasi Samba File Server itu sendiri.

Server dapat dengan mudah mengakses seluruh data klien yang ada pada server. Setelah file server berjalan maka ada beberapa hal yang perlu diperhatikan, yaitu:

a. Dalam melakukan login ke file server, setiap user terlebih dahulu telah di add ke file server.

b. Setiap user yang akan melakukan login hendaknya meng-inputkan username dan password yang benar.

c. Serta log on ke file server dengan menginputkan "lab2"

d. Pada saat menyimpan file maka pilihlah directory yang telah dikonfigurasi sebagai media penyimpanan bersama agar file yang tersimpan langsung masuk ke dalam server.

2. Remote desktop dengan VNC(Virtual Network Computing).

Untuk remote desktop dari Ubuntu ke Windows, dengan kata lain Ubuntu berperan sebagai server atau pengontrol dan Windows sebagai klien, tidak perlu melakukan instalasi VNC pada Ubuntu karena paket ini telah menjadi fitur yang disediakan oleh Ubuntu. Sedangkan pada Windows harus terlebih dahulu diinstalkan yang mana softwarenya dikenal dengan nama RealVNC.

Setelah melakukan instalasi pada Windows selanjutnya bisa melakukan remote dari Ubuntu dengan meng-inputkan alamat IP klien yang akan dikonttrol. Sehingga apapun yang dilakukan oleh klien dapat dilihat oleh 


\section{KESIMPULAN}

Dari hasil perancangan, implementasi serta pengujian yang telah dilakukan, maka dapat diambil kesimpulan sebagai berikut:

1. Samba File Server memudahkan pengguna linux untuk berhubungan dangan Windows dalam hal sharing, penggunaan direktori bersama, dan fungsi yang lainnya karena tool yang diberikannya.

2. Keuntungan menggunakan VNC ini adalah kemudahan yang diberikan untuk dapat mengontrol kegiatan klien tanpa harus melakukan tinjauan langsung ke klien.

3. Untuk bisa mengendalikan komputer lain, dibutuhkan alamat IP yang digunakan oleh komputer tujuan.

\section{REFERENSI}

[1] Gunendro, Tri. Samba Sebagai Penghubung Jaringan Linux Dengan Windows/DOS. Palembang. Politeknik Negeri Sriwijaya. 2007.

[2] Hariri, Anis. Integrasi Jaringan UnixWindows. Jakarta. Penerbit PT Elex Media Komputindo, 2002.

[3] Irawan, Budhi. Jaringan Komputer. Yogyakarta. Graha Ilmu. 2005.

[4] Nugroho, Bunafit. Instalasi \& Konfigurasi Jaringan Windows \& Linux. Yogyakarta. Penerbit Andi, 2005.

[5] Penerbit Andi. Langkah Mudah Administrasi Jaringan Menggunakan Linux Ubuntu 9. Semarang : Wahana Komputer, 2009.

[6] Sukmaaji, Anjik \& Rianto. Jaringan Komputer. Yogyakarta. Penerbit Andi. 2008.

[7] Sidik, Betha. Unix \& Linux (Panduan Bekerja dalam Lingkungan Unix Dan Linux). Bandung. Penerbit Informatika, 2004.

[8] Sugeng, Winarno. Jaringan Komputer dengan TCP/IP. Bandung : Informatika. 2006.

[9] Tisgatiani, Ririn. Membangun VNC (Virtual Network Connection) Server Pada Server Linux. Palembang. Politeknik Negeri Sriwijaya. 2007.

[10] W. Purbo. Onno. PC Cloning Windows Pakai Linux LTSP. Yogyakarta. Penerbit Andi. 2006.

[11] Wulan Nirwana, Fika. Server Message Block (SMB) Pada Samba Server. Palembang. Politeknik Negeri Sriwijaya. 2007. 